\title{
Proceeding
}

Supplementary Issue: Winter Conferences of Sports Science. Costa Blanca Sports Science Events, 25-26 January 2019.

Alicante, Spain

\section{Principles of adaptation of the rules for disabled athletes for an inclusion sport}

\author{
LUCIANA MARTINO $\triangle$, ERMINIO FONZO, FRANCESCO PELUSO CASSESE, TIZIANA D'ISANTO \\ University of Salerno, Italy
}

\begin{abstract}
One of the aims of the adapted physical activity, APA, is the sport for disabled athletes with specific rules and applied only to the specific category of disabled people who compete under the government of the International Paralympic Committee, IPC, and Special Olympics, SO. The study wants to hypothesize adaptation processes for races open also to other categories of disabled athletes and normal people throughout changes to sports facilities and rules of the sport. The method is that of qualitative research of group work with specific focus after individual elaborations of several students attending the master's degree course in the evaluation of disabled people. The phases are as follows: 1) elaboration of specific ideas for individual sports adapted by the sample of 55 master students; 2) focus groups on analysis and discussion of the problems highlighted in the individual projects; 3 ) synthesis of the principles and guidelines related to adaptation of race rules and sport facilities. The results shows the selected sport, its adaptation of single race rules and its sport facilities. Number 33 of sports have been hypothesized: 17 individual sports and 16 team ones. This work can create new sports, in which it can compete together athletes with different disabilities , and you can also highlight that in sport, as in life, if we overcome all barriers and limits, mental and physical, nothing is impossible. Inclusive paradigm has to be developed in sport also for the race effect. Key words: Diversity; Rules; APA; IPC; SO.
\end{abstract}

\section{Cite this article as:}

Martino, L., Fonzo, E., Cassese, F.P., \& D'Isanto, T. (2019). Principles of adaptation of the rules for disabled athletes for an inclusion sport. Journal of Human Sport and Exercise, 14(2proc), S215-S220. doi:https://doi.org/10.14198/ihse.2019.14.Proc2.08

Corresponding author. University of Salerno, Italy.

E-mail: I.martino95@tiscali.it

Supplementary Issue: Winter Conferences of Sports Science. Costa Blanca Sports Science Events, 25-26 January 2019. Alicante, Spain.

JOURNAL OF HUMAN SPORT \& EXERCISE ISSN 1988-5202

(C) Faculty of Education. University of Alicante.

doi:10.14198/jhse.2019.14.Proc2.08 


\section{INTRODUCTION}

With the term APA "Adapted Physical Activity" we identify the Adapted Physical and Sport Activity which has different aims, but its central focus is the individual differences in physical activity that require special attention, and which include impairments, disability, handicap and other special needs, therefore, refers to movement, physical activity and sports aimed at the interests and abilities of people with special needs. "It refers to movement, physical education, rehabilitation and sports in which particular emphasis is given to the interests and abilities of individuals characterized by limited physical conditions, such as the disabled, the sick or the elderly, is aimed at people with physical limitations and with chronic diseases "(ADAPT, 2004) and includes several areas, including adapted physical education, recreational activities of social recovery, dance and creative movement, sport, rehabilitation and, very important, the physical-motor maintenance for the improvement of the lifestyle. (Gaetano, 2016).

One of the aims of the adapted physical activity, APA, is the sport for disabled athletes with specific rules and applied only to the specific category of disabled people who compete under the government of the International Paralympic Committee, IPC, and Special Olympics, SO. (D'elia, 2019, Raiola, et al.,2015).

The IPC is the international organization that governs the Paralympic sport that organizes the summer and winter Paralympic Games, and serves as the International Confederation for 12 sports, which then supervises and coordinates the organization of the World Championships and other competitions. The mission of the International Paralympic Committee is to allow disabled athletes to achieve excellence in sports and to create sports opportunities for everyone at any level. In addition, the ICC has as its goal the promotion of Paralympic values, which include courage, determination, inspiration and equality.

The SO is the world's largest sports organization for children and adults with intellectual disabilities.(D'elia,2019). The study wants to hypothesize adaptation processes for races open also to other categories of disabled athletes and normal people throughout changes to sports facilities and rules of the sport. (Cassese, Raiola, 2017).

\section{METHODS}

The research method used is qualitative, consisting in the collection of observable information not in numerical form, but through a series of classifications. Data are usually acquired through the use of a diary, an open questionnaire, interviews or unstructured observations and are mainly descriptive data.

Qualitative research is useful in studies on individual cases and to describe a specific event or behaviour. (Altavilla, et al.,2015).

Basically, it is a matter of expressing the qualities of a certain object of investigation in the form of textual information through, for the most part, unstructured investigation tools. Qualitative research, in short, focuses on the collection of mainly verbal data, rather than on numerical measurements. Therefore, the information collected is then analysed in an interpretative, subjective way, even if there are statistical tools that allow us to achieve accurate and reliable results as much as possible. The following techniques / tools fall within the qualitative methods: structured, semi-structured and unstructured interviews, various types of observation and focus groups. 
In this research, we asked a sample of 55 students to choose a sport, individual or group, and change the rules of that discipline or create new ones so that the discipline became inclusive and practicable at the same time by disabled and non-disabled athletes. The method is that of qualitative research of group work with specific focus after individual elaborations of the group of students attending the master's degree course in the evaluation of disabled people. (D'Isanto, et al.,2016).

The phases are as follows:

1) elaboration of specific ideas for individual sports adapted by the sample (eg 55 master students);

2) focus groups on analysis and discussion of the problems highlighted in the individual project ideas;

3) synthesis of the principles related to the type of adaptation of competition rules and learning environments.

\section{RESULTS}

The results of this work have been reported on a table (table 1) and shows the selected sport, its adaptation of single race rules and its sport facilities. Number 33 of sports have been hypothesized: 17 individual sports and 16 team ones. Below is a part of the table that shows the name of the students in the first column, the sport chosen in the second one and in the third the rules modified for that sport.

Table 1. Table of sport rules

\begin{tabular}{|c|c|l|}
\hline Student & Sport & Basic rules \\
\hline 1. & Baseball & $\begin{array}{l}\text {-The roles that can hold subjects with disabilities are: pitcher and receiver. } \\
\text { To the first, to subjects with deafness the beginning of the bar marked with visual } \\
\text { devices. } \\
\text {-In cases of blind subjects } \diamond \text { acoustic signal devices to warn the beginning of the } \\
\text { game. }\end{array}$ \\
\hline 2. & Dance & $\begin{array}{l}\text {-The combi category consists of two components, one of which is disabled. } \\
\text {-The disability can be of any type, physical, sensorial, or intellectual-relational. } \\
\text {-For those with hearing disabilities -> not being able to hear the music, they are } \\
\text { able to perceive the sound vibrations that propagate in the room. The higher the } \\
\text { volume of music the more the vibrations are received. } \\
\text {-An additional support can be provided by the technology with Vibetunes, an } \\
\text { application for android that is able to "listen" to the deaf music on their mobile } \\
\text { phone. }\end{array}$ \\
\hline 3. & $\begin{array}{l}\text { Paralympic } \\
\text { judo }\end{array}$ & $\begin{array}{l}\text {-For a duel between blind athlete and able-bodied athlete they bandage both } \\
\text { (even the blind athlete) to ensure the same degree of visibility. } \\
\text {-the two blindfolded athletes start the fight and from the angle the coaches give } \\
\text { - their athletes all the information they need to fight } \\
\text { fencing) and both announce the guard (right or left) with whom they intend to } \\
\text { advance. }\end{array}$ \\
\hline
\end{tabular}




\begin{tabular}{|c|c|c|}
\hline 4. & Rugby & $\begin{array}{l}\text {-Including sports in which the disabled compete on wheelchairs equipped with } \\
\text { sensors that move thanks to the movement of the torso to facilitate subjects with } \\
\text { amputations to the arms. } \\
\text { - Light and medium severe visas compete with appropriate visual corrections } \\
\text { - The ball will have a rounded shape. It will be bigger, made of rubber for better } \\
\text { rebounds and sound, to help people suffering from blindness. } \\
\text {-The poles are less high to allow you to make more easily. }\end{array}$ \\
\hline 5. & $\begin{array}{l}\text { Track } \\
\text { cycling }\end{array}$ & $\begin{array}{l}\text { - Reference categories: blind and able-bodied } \\
\text {-Tandem race, blind and able-bodied and only the } 1000 \text { meter race is scheduled } \\
\text { and the tandem will be built according to the prostheses of disabled athletes and } \\
\text { with the assembly of the power meter on the crank. } \\
\text { - Two parameters with the assignment of a score related to lap time and power } \\
\text { measurement (Watt) expressed by the blind athlete. } \\
\text { - Modifications to the rules for the attribution of the score and preparation of the } \\
\text { ranking on the basis of the scores obtained. -The blind athlete is made active } \\
\text { participant of the competition. }\end{array}$ \\
\hline 6. & Handball & $\begin{array}{l}\text { Adaptation of the handball that possesses particular and innovative } \\
\text { characteristics; } \\
\text { - A game played by two teams each made up of } 7 \text { players, two of them in the } \\
\text { role of goalkeeper. } \\
\text { - Each player has a role defined by his motor skills and has a direct opponent of } \\
\text { the same level. These roles are numbered from } 1 \text { to } 5 \text { and have their own rules; } \\
\text { - there are side doors in addition to the base ones; } \\
\text { - there is the possibility of replacing the regulation ball with a reduced size and } \\
\text { weight in certain game situations; } \\
\text { - there is the possible assignment of a tutor, ie a player of the team can } \\
\text { accompany the actions of a fellow with disability. }\end{array}$ \\
\hline 7. & Kitebowls & $\begin{array}{l}\text {-Sport team that combines the basic principles of the Paralympic bowl, curling } \\
\text { and golf. } \\
\text { - Each team is composed of } 8 \text { heterogeneous players and they challenge each } \\
\text { other to the best of the } 3 \text { sets. } \\
\text {-Players must throw the ball from each of the corners of the field (called stations) } \\
\text { towards the centre, where there is a circular area with concentric rings (as in } \\
\text { curling), each with a certain value, which increases the more you approaching } \\
\text { the centre: the outermost one is worth } 5 \text { points, then up the narrowest ring that } \\
\text { is worth } 100 \text { points. At the centre of the area there is a hole (as in golf) } \\
\text {-It takes its name from the shape of the kite field and from the main object of the } \\
\text { game that are the bowls. } \\
\text {-Including sport able to unite athletes with different disabilities in a single team, } \\
\text { guaranteeing equal opportunities to play for everyone }\end{array}$ \\
\hline 8. & $\begin{array}{c}\text { Wheelchair } \\
\text { curling }\end{array}$ & $\begin{array}{l}\text { To include the able-bodied persons, the sweeping phase is not present; } \\
\text {-The able-bodied perform the garbage phase as provided by the classic curling } \\
\text { - The wheelchair subjects will move on the ice through an overboard mechanism }\end{array}$ \\
\hline
\end{tabular}




\begin{tabular}{|l|l|l|}
\hline & $\begin{array}{l}\text { incorporated in the wheelchair. In this way they can sweep with the broom while } \\
\text { they move with the trunk } \\
\text { - For the launch phase they will all launch while sitting on the wheelchair and it } \\
\text { will be held still for more stability by the companions. } \\
- \text { The other rules such as scoring and playing field are the same as wheelchair } \\
\text { curling }\end{array}$ \\
\hline 9. & Table tennis & $\begin{array}{l}\text { - The single game ends at } 10 \text { points, in case of a tie from } 10 \text { points the game } \\
\text { goes on until one of the two players is the first to get two points more than the } \\
\text { opponent. } \\
\text { - Each player has two rackets, one for each hand. After the joke the opponent } \\
\text { responds with one of the two rackets (left or right) and the counter-response } \\
\text { must use the racket opposite to that used in the service. } \\
\text {-The use of two rackets allows the disabled player not to move too far from one } \\
\text { side to the other, thus helping himself with both hands. }\end{array}$ \\
\hline
\end{tabular}

\section{DISCUSSION}

From the analysis carried out, through the qualitative method of the focus group we understand how new principles have been created for various sports and both team and individual sports have been chosen. The table shows how the rules of the game were modified, sometimes the rules of the game, in other sports the duration of the game times, other times the equipment and finally the roles to assign to each component (disabled or not).

\section{CONCLUSION}

The results showed that new sports were born that give everyone the opportunity to compete together without any distinction and these changes to these sports could create as well as inclusion and integration, even more competitiveness among athletes, because they should try to overcome themselves and their limits to make it. (Raiola, et al., 2018, Raiola, 2015).

In conclusion, with this work not only can you create "new" sports in which you can compete on a parity with both able-bodied and non-athletes, but you can understand that in sport, as in life, if we overcome all the barriers and limits, mental and physical, nothing is impossible.

\section{REFERENCES}

Altavilla, G., Furino, F., Marika, D.P., Raiola, G. (2015). Physical skills, sport learning and socio-affective education [Fizičke vještine, sportsko učenje I društveno-afektivno obrazovanje] Sport Science, 8, pp. 44-46.

Cassese, F.P., Raiola, G. (2017). The importance of sport in disability management [Važnost sporta u upravljanju kod invaliditeta] Sport Science, 10, 7-11.

D'Elia, F. (2019). The training of physical education teacher in primary school. Journal of Human Sport and Exercise, 14(1 proc), S100-S104. https://doi.org/10.14198/ihse.2019.14.Proc1.12 
D'Elia, F., Mazzeo, F., Raiola, G. (2018)The core curriculum in the university training of the teacher of physical education in Italy, Journal of Human Sport and Exercise, 13(Proc2): S413-S420. https://doi.org/10.14198/ihse.2018.13.Proc2.25

D'Isanto, T., D'Elia, F., Raiola, G., \& Altavilla, G. (2019). Assessment of sport performance: theoretical aspects and practical indications. Sport Mont, 17(1), 79-82. https://doi.org/10.26773/smj.190214

D'Isanto, T., Di Tore, P.A. (2016). Physical activity and social inclusion at school: A paradigm change. Journal of Physical Education and Sport, 16, pp. 1099-1102.

Di Tore, A.P., Raiola, G., D'Isanto, T. (2018). Situation awareness in sports science: Beyond the cognitive paradigm [Situacijska svijest u sportskoj nauci: Van kognitivne paradigme], Sport Science, 11 (1), 44-48.

Di Tore, P.A., Raiola, G., Altavilla, G., Barba, S., Pignato, S., Lipoma, M. (2016). Motor imagery, perspective taking and gender differences: A VVIQ2-based study. Journal of Human Sport and Exercise, 11 228-232. https://doi.org/10.14198/ihse.2016.11.Proc1.13

Di Tore, P.A., Schiavo, R., D'Isanto, T. (2016). Physical education, motor control and motor learning: Theoretical paradigms and teaching practices from kindergarten to high school. Journal of Physical Education and Sport, 16 (4), 1293-1297.

Gaetano, A. (2016). Relationship between physical inactivity and effects on individual health status, Journal of Physical Education and Sport, 16, 1069-1074.

Gaetano, R. (2012). Motor learning and didactics into physical education and sport documents in middle school-first cycle of education in Italy, Journal of Physical Education and Sport, 12 (2), 157-163.

Raiola, G., D'Elia, F., \& Altavilla, G. (2018). Physical activity and sports sciences between European research council and academic disciplines in Italy. Journal of Human Sport and Exercise, 13(2proc), S283-S295. https://doi.org/10.14198/jhse.2018.13.Proc2.13

Raiola, G. (2011)A study on Italian primary school rules: Neurophysiological and didatics aspects $n$ phisical education and sport, Journal of Physical Education and Sport, 11 (2), 43-48.

Raiola, G. (2015)Sport skills and mental health, Journal of Human Sport and Exercise, 10 369-376. https://doi.org/10.14198/ihse.2015.10.Proc1.27

Raiola, G., Altavilla, G., Filippo, G.P. (2015)Effects of physical activity and sports in the reduction of stereotypy in blind subjects [Učinci tjelesne aktivnosti i sporta u smanjenju stereotipa kod slijepih subjekata] Sport Science, 8, pp. 52-55.

\section{(9) $(\mathcal{Q} \Theta \Theta$}

This work is licensed under a Attribution-NonCommercial-NoDerivatives 4.0 International (CC BY-NC-ND 4.0). 